\title{
The DTED. Curriculum / Syllabus of the State Tamilnadu In Inidia And Performance of Student Teachers
}

\author{
S.Vincent De Paul ${ }^{1}$, S.Thangarasu ${ }^{2}$ and G.Murugan ${ }^{3}$ \\ ${ }^{1}$ Reader, State Council of Educational Research and Training, DPI Campus, College Road, Chennai,600006, \\ Tamilnadu, India \\ ${ }^{2}$ Lecturer, District Resource Unit, District Institute of Education \& Training, Pudukkottai 622004 \\ ${ }^{3}$ Lecturer, Planning \& Management Branch, District Institute of Education \& Training, Pudukkottai 622004
}

\begin{abstract}
In developing country like India curriculum revision is a continuous process and particularly in teacher education, curriculum is revised periodically. Recently NCTE has designed and approved National Curriculum Framework for Teacher Education (NCFTE) 2009 with a wide scope for restructuring Teacher Education in India and establishing linkage between Elementary Teacher Education and Higher Education. This NCFTE (2009) document has gained a singular important as it has been released by Honorable Minister for HRD, GOI, on 10 th March 2010. The apex body for Elementary-Teacher Education in Tamil Nadu namely Directorate of Teacher Education Research and Training (DTERT), presently State Council of Educational Research and Training (SCERT) has developed Elementary Teacher Education Curriculum and Syllabus to address the needs of the present elementary school teaching learning process based on National Curriculum Framework for Teacher Education (2005). An attempt is made to study the performance of DTEd students based on the revised curriculum \& syllabus followed in the State, Tamil Nadu, India.
\end{abstract}

Key Words: Elementary Teacher Education, Curriculum, Syllabus, Taught Course, Internship, Performance, Marks, Grades.

\section{Introduction}

The shaping of the future of a nation depends on the teachers and the education they provide in schools. In the present Communication era the word 'teacher' has a wide and undefined meaning. The teacher acts as a fulcrum for providing learning environment to the learner so that the learner can construct the knowledge by himself / herself. Individuals involved in imparting knowledge or information, whether through formal or informal means, to a single person or group of persons are called "teachers" (Atan Long, 1984). Social scientists label teachers as educators, teachers, trainers and leaders who are responsible for imparting knowledge, defining behavior and leading by way of examples to students.

The most important duty of a teacher is to execute processes and educational pedagogy that enables objective-based learning and define quality and effective behavior patterns (Gani et al., 2008). It is well known that teachers' knowledge on content plays a significant role in shaping the quality of their teaching (Hill et al., 2005). To cope with the contemporary issues in teaching learning process and school activities a strong well designed teacher educational curriculum is needed. The curriculum developers of our Nation viz, National Council for Teacher Education (NCTE) and National Council of Educational Research and Training (NCERT) have developed National Curriculum Framework for Teacher Education (2005). In developing country like India curriculum revision is a continuous process and particularly in teacher education curriculum is revised periodically. Recently NCTE has designed and approved National Curriculum Framework for Teacher Education (NCFTE) 2009 with a wide scope for restructuring Teacher Education in India and establishing linkage between Elementary Teacher Education and Higher Education. This NCFTE (2009) document has gained a singular important as it has been released by Honorable Minister for HRD, GOI, on $10^{\text {th }}$ March 2010. The apex body for Elementary Teacher Education in Tamil Nadu namely Directorate of Teacher Education and Research (DTERT), presently State Council of Educational Research and Training (SCERT) has developed Elementary Teacher Education Curriculum and Syllabus to address the needs of the present elementary school teaching learning process based on National Curriculum Framework for Teacher Education (2005).

\section{National Curriculum Framework for Teacher Education (2005)}

The universal participation in Elementary Education in India depends on the quality that exists in schools which are the mirror image of Quality in Teacher education. Teacher qualifications are significant in improving standards within our schools. Floden, et al. (2001) suggested a strong relationship between teacher preparation and teacher effectiveness. The teacher quality is the most crucial contributory factor for student achievement ( Hanushek et al., 2001; Saunders et al., 1994). The teacher education programme reflects the quality of school directly and real life indirectly. Kothari Commission (1964-66) says that the professional 
preparation of teachers should be recognized as a crucial factor for the qualitative improvement of education. The report of the Chattopadhyaya Committee (National Commission on Teachers 1983-85) envisioned the new teacher as one who communicates to pupils effectively. The National Policy of Education (NPE, 1986) and Programme of Action (POA, 1992) recognized that "...teachers should have the freedom to innovate, to devise appropriate methods of communication and activities relevant to the needs and capabilities of and the concerns of the community." The Yashpal Committee Report (1993) on 'Learning without Burden' argued that "....inadequate programmes of teacher preparation lead to unsatisfactory quality of learning in schools. Hence the Government of India took major steps in revising and revamping teacher education curriculum to improve quality in school education and quality in life.

In National Curriculum Framework School Education (NCF, 2005), teachers are being posed as crucial mediating agents through which curriculum is transacted. The two important concerns of the NCF (2005) are connecting knowledge to life outside the school and enriching the curriculum by making it less textbookcentered. It stresses that teachers should know how to provide learning experiences / environment through which a learner can construct knowledge in the classroom and apply the same in real life situations. In other words teacher trainee should be given the learning environment by the teacher educator which will help him/ her to promote the constructivist approach in his real classroom.

The NCF (2005) rightly points out that 'the nature of any teacher education programme, in its substance and methodology is influenced by the way teaching is conceptualized, be it a scientific endeavour or an artistic one. Despite the fact that teaching has a strong foundation of knowledge and skills, as a process it calls for intuition, improvisation, expressiveness and creativity. The teacher education curriculum must provide for both these inseparable aspects of teaching'.

\section{Curriculum and Syllabus for Diploma in Teacher Education Programme in Tamil Nadu}

The DTERT renewed the curriculum and syllabus in the light of NCFTE (2005). The new syllabus and source books were introduced from the academic year 2008-09. It aims at the preparation of committed teachers whose professionalism would enable them to sustain their learning interest throughout their career. (Tamil Nadu Government Gazette, 41A). It focuses learner centred and ways and means of facilitating and enhancing learning by children.

\subsection{Objectives of the Course}

The Diploma in Teacher Education course has the following objectives as per the Gazette. At the end of the course, the teacher trainee will be able to

$>$ understand the nature, purpose, problems and issues of elementary education,

$>$ evolve need-based, community-specific and child-centered pedagogy including indigenous learning systems,

$>$ understand the nature and maturity level of children for imparting education for their many sided development,

$>$ to mobilize and manage community resources for the development of school infrastructure,

$>$ use the constructivist pedagogy and evaluation techniques,

$>$ develop desire, taste and capacity for life-long learning and make them aware of the latest developments in their areas of specialization and the needed transactional skills,

$>$ understand the advantages of ICT and use the same for facilitating student learning,

$>$ develop sensitivity towards the education of the neglected sections of society who are deprived of the rights they are entitled to and

$>$ participate in the effective management of the school.

\subsection{Duration}

The duration of the course is two academic years with 220 working days in a year. In the first year the transaction takes place for about 1100 hours.(Table 1)

Table 1: First Year Course-work and Hours Allotted

\begin{tabular}{|l|c|}
\hline \multicolumn{1}{|c|}{ Course Work Details } & Hours Allotted \\
\hline 4 Days of Child Observation and doing Case Study & 20 \\
\hline 4 Days of School Visit & 20 \\
\hline 40 Days of Internship & 200 \\
\hline 172 Days of Class work (Theory and Practicum) & 860 \\
\hline Total & 1100 \\
\hline
\end{tabular}

In the Second year the transaction takes place for about 1100 hours. (Table 2) 
The Dted. Curriculum / Syllabus of The State Tamilnadu In Inidia And Performance of Student

Table 2: First Year Course-work and Hours Allotted

\begin{tabular}{|l|c|}
\hline \multicolumn{1}{|c|}{ Course Work Details } & Hours Allotted \\
\hline 8 Days of Project Related Work & 40 \\
\hline 40 Days of Internship & 200 \\
\hline 172 Days of Class work (Theory and Practicum) & 860 \\
\hline Total & 1100 \\
\hline
\end{tabular}

\subsection{Eligibility for Admission}

A pass in Higher Secondary or any equivalent examination conforming to the norms set by NCTE / State Government, if any is the eligible conditions to undergo the course.

\subsection{Taught Courses, Transaction, and Evaluation}

Each year two core papers and five subject papers (both Content and Methodology) are offered. Each core and subject paper is taught for 100 hours per year. The details are given in the Tables 3 and 4 .

Table 3: First Year Taught Courses, Transaction, and Evaluation

\begin{tabular}{|l|c|c|c|}
\hline \multirow{2}{*}{ Taught Courses } & \multirow{2}{*}{$\begin{array}{c}\text { Time } \\
\text { in Hours }\end{array}$} & \multicolumn{2}{c|}{ Marks } \\
\cline { 3 - 4 } & 100 & 100 & External \\
\hline The Learning Child & 100 & 100 & 25 \\
\hline Facilitating \& Enhancing Learning-I & 100 & 100 & 25 \\
\hline $\begin{array}{l}\text { Teaching of Tamil /Urdu / Malayalam / } \\
\text { Telugu-I }\end{array}$ & 100 & 100 & 25 \\
\hline Teaching of English-I & 100 & 100 & 25 \\
\hline Teaching of Mathematics-I & 100 & 100 & 25 \\
\hline Teaching of Science -I & 100 & 100 & 25 \\
\hline Teaching of Social Science-I & 700 & 700 & 200 \\
\hline Total & &
\end{tabular}

Table 4: Second Year Taught Courses, Transaction, and Evaluation

\begin{tabular}{|l|c|c|c|}
\hline \multirow{2}{*}{\multicolumn{1}{c|}{ Taught Courses }} & \multirow{2}{*}{ Time } & \multicolumn{2}{c|}{ Marks } \\
\cline { 3 - 4 } & in Hours & External & Internal \\
\hline Indian Education System & 100 & 100 & 25 \\
\hline Facilitating \& Enhancing Learning-II & 100 & 100 & 25 \\
\hline $\begin{array}{l}\text { Teaching of Tamil /Urdu / } \\
\text { Malayalam / Telugu-II }\end{array}$ & 100 & 100 & 25 \\
\hline Teaching of English-II & 100 & 100 & 25 \\
\hline Teaching of Mathematics-II & 100 & 100 & 25 \\
\hline Teaching of Science -II & 100 & 100 & 25 \\
\hline Teaching of Social Science-II & 100 & 100 & 25 \\
\hline Total & 700 & 700 & 200 \\
\hline
\end{tabular}

External examination in the first seven Taught Courses is conducted for 100 marks in each subject for both years separately. In general the core papers are assessed by the Short Answer Questions (about 100 words) with no choice of 15 questions (30 marks), Paragraph Answer Questions (about 200 words) 10 out of 12 (40 marks), and Essay Questions (about 500 words) 3 with internal choice (30 marks).

In the external examination of the taught courses, Teaching of Tamil /Urdu / Malayalam / Telugu, Teaching of English, Teaching of Mathematics, Teaching of Science and Teaching of Social Science. 40\% weight-age is given to Content up to X Standard level and 60\% weight-age to methodology. In the Subject papers content parts are assessed by the Short Answer Questions (about 100 words) with no choice of 10 questions (20 marks), and Paragraph Answer Questions (about 200 words) 5 out of 8 (20 marks). Similarly the Methodology parts are assessed by the Short Answer Questions (about 100 words) with no choice of 10 questions (20 marks), Paragraph Answer Questions (about 200 words) 5 out of 8 (20 marks), and Essay Questions (about 500 words) 2 with internal choice (20 marks).

Besides the External Examination, Internal Assessment is made by the Board of Examiners constituted from outside the institute where the trainee studies, for the taught course separately in each year, which is based on the continuous comprehensive assessment made by the subject teachers of the own institute. The evolution is done as per the pattern given in the Table 5.To get a pass in the course each trainee should get 50\% marks in each core and subject paper in both external and Internal separately. The details are given in the Table 5 


\begin{tabular}{|c|c|c|}
\hline \multicolumn{3}{|c|}{ Tables 5: Internal Assessment for Taught Courses } \\
\hline .Taught Course & Activities & Marks \\
\hline \multirow{5}{*}{$\begin{array}{l}\text { Learning Child, Facilitating \& } \\
\text { Enhancing Learning and } \\
\text { Indian Education System }\end{array}$} & Practicals suggested in the units & 5 \\
\hline & $\begin{array}{l}\text { Subject-specific tasks other than suggested in the } \\
\text { units }\end{array}$ & 5 \\
\hline & Test & 5 \\
\hline & Seminar & 5 \\
\hline & Review of Two books & 5 \\
\hline \multirow{5}{*}{$\begin{array}{l}\text { Teaching of Tamil /Urdu / } \\
\text { Malayalam / Telugu, Teaching } \\
\text { of English, Teaching of } \\
\text { Mathematics, Teaching of } \\
\text { Science and Teaching of } \\
\text { Social Science. }\end{array}$} & Practicals suggested in the units & 5 \\
\hline & $\begin{array}{l}\text { Subject-specific tasks other than suggested in the } \\
\text { units }\end{array}$ & 5 \\
\hline & Test & 5 \\
\hline & Seminar 2 & 5 \\
\hline & $\begin{array}{l}\text { Preparation of question banks containing all types } \\
\text { of questions (both objective and subjective) in each } \\
\text { unit in the school syllabus and one unit in the } \\
\text { course syllabus }\end{array}$ & 5 \\
\hline
\end{tabular}

\subsection{Practicum, Transaction, and Internal Assessment}

The Trainees do six practicals in each year under practicum. In the first year each practical is taught for 40 hours except the practicals, Observing Children \& doing Case Study and School Visit. These two are taught for each 20 hours. In the second year each practical is taught for 40 hours except the practicals, Teaching Learning Materials and Art Education \& Work Experience. These two are taught for each 20 hours. Internal Assessment is made by the Board of Examiners constituted from outside the institute where the trainee studies, for practicum course separately in each year, which is based on the continuous comprehensive assessment made by the subject teachers of the own institute. The maximum mark is 100 for all the practical subjects each except Observing Children and doing Case Study which carries 125 marks. To get a pass in the practicum trainee should get 50\% marks (that is ' $\mathrm{C}$ ' grade) in each practical. The marks awarded are expressed in terms of Grades. The details are given in the Tables 6 and 7.

Table 6: First Year -- Practicum, Transaction, and Evaluation

\begin{tabular}{|c|c|c|c|c|c|c|}
\hline \multirow[b]{2}{*}{ Taught Courses } & \multirow{2}{*}{$\begin{array}{l}\text { Time in } \\
\text { Hours }\end{array}$} & \multirow{2}{*}{ Marks } & \multicolumn{4}{|c|}{ Grade } \\
\hline & & & $\begin{array}{l}75 \% \\
\text { Above }\end{array}$ & $\begin{array}{c}60-74 \\
\%\end{array}$ & $\begin{array}{l}50- \\
59 \%\end{array}$ & $\begin{array}{l}\text { Below } \\
50 \%\end{array}$ \\
\hline $\begin{array}{l}\text { Observing Children and doing Case } \\
\text { Study }\end{array}$ & 20 & 125 & A & $\mathrm{B}$ & $\mathrm{C}$ & $\mathrm{D}$ \\
\hline School Visit & 20 & 100 & A & B & $\mathrm{C}$ & $\mathrm{D}$ \\
\hline Story Telling & 40 & 100 & $\mathrm{~A}$ & $\mathrm{~B}$ & $\mathrm{C}$ & $\mathrm{D}$ \\
\hline $\begin{array}{l}\text { Physical Education, Health Education } \\
\text { \& Yoga I }\end{array}$ & 40 & 100 & A & B & $\mathrm{C}$ & $\mathrm{D}$ \\
\hline Self- Development workshop I & 40 & 100 & $\mathrm{~A}$ & $\mathrm{~B}$ & $\mathrm{C}$ & $\mathrm{D}$ \\
\hline Teaching Learning Materials I & 40 & 100 & A & $\mathrm{B}$ & $\mathrm{C}$ & $\mathrm{D}$ \\
\hline Total & 200 & 625 & -- & -- & -- & -- \\
\hline
\end{tabular}

Table 7: Second Year Practicum, Transaction, and Evaluation

\begin{tabular}{|c|c|c|c|c|c|c|}
\hline \multirow[b]{2}{*}{ Taught Courses } & \multirow{2}{*}{$\begin{array}{c}\text { Time } \\
\text { in } \\
\text { Hours }\end{array}$} & \multirow[b]{2}{*}{ Marks } & \multicolumn{4}{|c|}{ Grade } \\
\hline & & & $\begin{array}{c}75 \% \\
\text { Above }\end{array}$ & $\begin{array}{c}60- \\
74 \%\end{array}$ & $\begin{array}{l}50- \\
59 \%\end{array}$ & $\begin{array}{c}\text { Below } \\
50 \%\end{array}$ \\
\hline Self- Development Workshop II & 40 & 100 & $\mathrm{~A}$ & $\mathrm{~B}$ & $\mathrm{C}$ & $\mathrm{D}$ \\
\hline Teaching Learning Materials II & 20 & 75 & $\mathrm{~A}$ & $\mathrm{~B}$ & $\mathrm{C}$ & $\mathrm{D}$ \\
\hline $\begin{array}{l}\text { Physical Education, Health } \\
\text { Education \& Yoga II }\end{array}$ & 40 & 100 & A & $\mathrm{B}$ & $\mathrm{C}$ & $\mathrm{D}$ \\
\hline Art Education \& Work Experience & 20 & 75 & $\mathrm{~A}$ & $\mathrm{~B}$ & $\mathrm{C}$ & $\mathrm{D}$ \\
\hline Educational Computing & 40 & 150 & A & $\mathrm{B}$ & $\mathrm{C}$ & $\mathrm{D}$ \\
\hline Projects & 40 & 125 & A & $\mathrm{B}$ & $\mathrm{C}$ & $\mathrm{D}$ \\
\hline Total & 200 & 625 & -- & -- & -- & -- \\
\hline
\end{tabular}




\subsection{Internship, Internal Assessment for Teaching Competency}

As per the Gazette, each student-teacher has an intensive practice in observation-cum-teaching in an identified Government / Aided School for a period of 40 days each year. Internship will be preceded by studentteacher preparation (5 days) in the respective Teacher Training Institute. Teaching practice in each subject is assessed in each year by the Board of Examiners constituted from outside the institute where the trainee studies, which is based on the continuous comprehensive assessment made by the subject teachers of the own institute, as per the pattern viz., Teaching Practice in Schools (30) Teaching Practice in the DIETs/TTIs (20) and Observation (10). The maximum marks for each subject is 60 . The marks awarded are expressed in terms of Grades. To get a pass in the Internship trainee should get $50 \%$ marks (that is ' $\mathrm{C}$ ' grade) in each practical. The details are given in the Tables 8 and 9 .

Table 8: Internship, Internal Assessment for Teaching Competency (First Year)

\begin{tabular}{|l|c|c|c|c|c|}
\hline \multirow{2}{*}{\multicolumn{1}{c|}{ Internship Subject }} & \multirow{2}{*}{ Marks } & \multicolumn{5}{c|}{ Grade } \\
\cline { 3 - 6 } & & $\begin{array}{c}\mathbf{7 5 \%} \\
\text { Above }\end{array}$ & $\begin{array}{c}\mathbf{6 0 - 7 4} \\
\mathbf{\%}\end{array}$ & $\mathbf{5 0 - 5 9 \%}$ & $\begin{array}{c}\text { Below } \\
\mathbf{5 0 \%}\end{array}$ \\
\hline $\begin{array}{l}\text { Teaching of Tamil /Urdu / Malayalam / } \\
\text { Telugu-I }\end{array}$ & 60 & $\mathrm{~A}$ & $\mathrm{~B}$ & $\mathrm{C}$ & $\mathrm{D}$ \\
\hline Teaching of English-I & 60 & $\mathrm{~A}$ & $\mathrm{~B}$ & $\mathrm{C}$ & $\mathrm{D}$ \\
\hline Teaching of Mathematics-I & 60 & $\mathrm{~A}$ & $\mathrm{~B}$ & $\mathrm{C}$ & $\mathrm{D}$ \\
\hline Teaching of Science -I & 60 & $\mathrm{~A}$ & $\mathrm{~B}$ & $\mathrm{C}$ & $\mathrm{D}$ \\
\hline Teaching of Social Science-I & 60 & $\mathrm{~A}$ & $\mathrm{~B}$ & $\mathrm{C}$ & $\mathrm{D}$ \\
\hline Total & 360 & -- & -- & -- & -- \\
\hline
\end{tabular}

Table 9: Internship, Internal Assessment for Teaching Competency (Second Year)

\begin{tabular}{|c|c|c|c|c|c|}
\hline \multirow[b]{2}{*}{ Internship Subject } & \multirow[b]{2}{*}{ Marks } & \multicolumn{4}{|c|}{ Grade } \\
\hline & & $\begin{array}{c}75 \% \\
\text { Above }\end{array}$ & $\begin{array}{c}60-74 \\
\%\end{array}$ & $50-59 \%$ & $\begin{array}{c}\text { Below } \\
50 \%\end{array}$ \\
\hline $\begin{array}{l}\text { Teaching of Tamil /Urdu / } \\
\text { Malayalam / Telugu-II }\end{array}$ & 60 & A & B & $\mathrm{C}$ & $\mathrm{D}$ \\
\hline Teaching of English-II & 60 & A & B & $\mathrm{C}$ & $\mathrm{D}$ \\
\hline Teaching of Mathematics-II & 60 & A & $\mathrm{B}$ & $\mathrm{C}$ & $\mathrm{D}$ \\
\hline Teaching of Science -II & 60 & A & B & $\mathrm{C}$ & $\mathrm{D}$ \\
\hline Teaching of Social Science-II & 60 & A & $\mathrm{B}$ & $\mathrm{C}$ & $\mathrm{D}$ \\
\hline Total & 360 & -- & -- & -- & -- \\
\hline
\end{tabular}

\subsection{Student Teacher Performance}

Assessment of Student Teachers' performance plays a key role in educational reform. Student teachers' performance should be assessed regularly during and at the completion of the training programme. Assesmnet measures Student teachers' progress and provides performance feedback to the Teacher Educator and the Student teachers there by helping the system identifying further needs to improve their performance. The performance of trainees both in theory and practicum should be assessed. Performance in theory may be assessed in terms of Academic Achievement in the taught courses. Academic Achievement means the knowledge attained or skill developed, as measured by scores, or assigned by the teacher or both in the terminal examination conducted in the course of an academic year. The good academic achievement of teacher trainees may have an effect on the performance of students in the regular classroom. The practicum and Internship may be better assessed by Continuous Comprehensive Evaluation both by the own teacher educator (internal) and the board of examiners (external) constituted by the apex body. The New Curriculum and syllabus provide a holistic platform for both theoretical assessment through summative evaluation and performance based assessment for practicum and Internship through Continuous Comprehensive Evaluation.

\section{Need For The Study}

In Tamil Nadu, based on the NCFTE (2005), new elementary Teacher Education Curriculum and Syllabus as described in the previous section was designed. The new syllabus based on new curriculum has been in transaction since 2008-09. How far the curriculum transaction has impacted the performance of trainees in theory, internal and practicum components of the syllabus will be helpful for teacher education to reflect on their engagement with trainees. The performance of trainees would reveal not only their theoretical grounding but also their improvement in their pedagogical repertoire through school internship programme and practicum. In short, the performance of trainees would bring forth the overall development of teachers in making. The present study 
speaks not only the academic achievement but also the personality development of teacher trainees which is the main focus of the new teacher education curriculum and syllabus.

\section{Objectives Of The Study}

1. To find out the achievement of Teacher trainees in the seven taught course

2. To find out the achievement of Teacher trainees in the Practicum

3. To find out the achievement of Teacher trainees in the Internship

\section{Hypothesis of The Study}

1. There exists no significant difference in mean achievement in the taught courses among the teacher trainees of Pudukkottai District with respect to the variable Type of Management of the Institute

2. There exists no significant difference in mean achievement in the taught courses among the teacher trainees of Pudukkottai District with respect to the variable Gender of the Teacher Trainees.

3. There exists no significant difference in mean achievement in the taught courses among the teacher trainees of Pudukkottai District with respect to the variable Age of the Teacher Trainees.

\section{Methodology}

Document analysis was followed in the present study using secondary data. This study is limited to the teacher Trainees of Pudukkottai District of Tamil Nadu only.

\subsection{Sample}

A total of 1911 first year teacher trainees of Diploma in Teacher Education (DTEd.,) appeared for the Examination in the District Pudukkottai of the State Tamilnadu. Results of the 18 teacher trainees were withheld by Directorate of Government Examination and 31 teacher trainees were absent for the examination. The absentees varied form single subject to all the two core and five subject papers. Thus complete details about the results were available only for 1862 teacher trainees. Hence the total sample for the present study was 1862 . The sample was further divided on the basis of type of Management of the training Institute, Gender and Age of the Teacher trainees.

\subsection{Tool}

The data were collected from the secondary Source data namely 'Tabulated Mark Sheet' of the training Institute concerned which was published by the Directorate of Government Examination, Chennai, functioning under School Education Department, Government of Tamilnadu.

\section{Analysis \& Interpretation}

The data were analyzed by using ' $t$ ' test and ' $F$ ' test.

\subsection{Achievement of Teacher Trainees in the Taught Courses}

The minimum, maximum, mean and Standard Deviation (SD) obtained for the two core papers and five taught courses are presented in the Table 10.

Table 10: Mean \& SD of the Taught Courses of the DTEd., Trainees of Pudukkottai District

\begin{tabular}{|l|c|c|c|c|c|}
\hline \multicolumn{1}{|c|}{ Taught Course } & N & Minimum & Maximum & Mean & SD \\
\hline The Learning Child & 1862 & 20.00 & 111.00 & 74.71 & 13.89 \\
\hline $\begin{array}{l}\text { Facilitating \& Enhancing } \\
\text { Learning-I }\end{array}$ & 1862 & 34.00 & 117.00 & 85.43 & 10.71 \\
\hline Teaching of Tamil-I & 1862 & 33.00 & 112.00 & 76.43 & 12.55 \\
\hline Teaching of English-I & 1862 & 20.00 & 109.00 & 57.01 & 16.71 \\
\hline Teaching of Mathematics-I & 1862 & 23.00 & 120.00 & 72.40 & 16.42 \\
\hline Teaching of Science -I & 1862 & 34.00 & 109.00 & 81.68 & 9.27 \\
\hline Teaching of Social Science-I & 1862 & 26.00 & 111.00 & 85.79 & 10.39 \\
\hline Total & 1862 & 279 & 734 & 533.46 & 62.04 \\
\hline
\end{tabular}

The mean and standard deviation of the achievement of the taught course of the teacher trainees have been found to be 533.46 and 62.04, respectively (Table 10). The maximum achievement score that could be obtained is 900 . The maximum score teacher trainees obtained in the present study has been 734 and the minimum 279. The mean score (533.46) is far above 59.27\% of the maximum score. So, it may be concluded that academic achievement of teacher trainees is rather high. The SD, 62.04, indicates that there is a slight wide dispersion of scores. 
Taught course-wise analysis of the academic achievement also shows that their performance is relatively high in all the seven taught courses except Teaching of English. (Table.10). Regarding the taught course 'The Learning Child', the achievement mean and SD have been found to be 74.71 and 13.89, respectively. Trainees are also good in the achievement at 'Facilitating \& Enhancing Learning-I' with the mean score of 85.43 and SD, 10.71. While their 'Teaching of Tamil I' achievement mean score is 76.43 and SD is 12.55 , their 'Teaching of English-I' have got the achievement mean of 57.01 and SD is 16.71. In Teaching of MathematicsI', their achievement mean is 72.40 and SD, 16.42. Their Teaching of Science -I' achievement mean score is found to be 81.68 with the SD of 9.27. While their performance in Teaching of Social Science-I' is relatively high with the achievement mean score of 85.79 and SD is 10.39, So it may be concluded that teacher trainees of Pudukkottai District teachers generally have high academic achievement in the taught courses. Taught coursewise analyses also support the general conclusion except in a single taught course namely 'Teaching of EnglishI' implying that teacher trainees are not performing enough to be competent in Teaching of English.

8.1.1. Testing the significance of difference in mean achievement in the taught courses among the teacher trainees of Pudukkottai District with respect to the variable Type of Management of the Institute

Table 11: ANOVA Summary

\begin{tabular}{|c|c|c|c|c|c|c|}
\hline $\begin{array}{l}\text { Name of the } \\
\text { Subject / Paper }\end{array}$ & Sources & $\begin{array}{l}\text { Sum of } \\
\text { Squares }\end{array}$ & $\mathrm{df}$ & Mean Square & $\mathrm{F}$ & Sig. \\
\hline \multirow{3}{*}{ Learning Child } & Between Groups & 8010.100 & 2 & 4005.050 & \multirow{3}{*}{21.202} & \multirow{3}{*}{0.01} \\
\hline & Within Groups & 351160.966 & 1859 & 188.898 & & \\
\hline & Total & 359171.066 & 1861 & & & \\
\hline \multirow{3}{*}{$\begin{array}{c}\text { Felicitating \& } \\
\text { Enhancing } \\
\text { Learning }\end{array}$} & Between Groups & 2309.512 & 2 & 1154.756 & \multirow{3}{*}{10.163} & \multirow{3}{*}{0.01} \\
\hline & Within Groups & 211217.995 & 1859 & 113.619 & & \\
\hline & Total & 213527.506 & 1861 & & & \\
\hline \multirow{3}{*}{$\begin{array}{l}\text { Teaching of } \\
\text { Tamil }\end{array}$} & Between Groups & 13670.546 & 2 & 6835.273 & \multirow{3}{*}{45.500} & \multirow{3}{*}{0.01} \\
\hline & Within Groups & 279271.738 & 1859 & 150.227 & & \\
\hline & Total & 292942.284 & 1861 & & & \\
\hline \multirow{3}{*}{$\begin{array}{l}\text { Teaching of } \\
\text { English }\end{array}$} & Between Groups & 5331.308 & 2 & 2665.654 & \multirow{3}{*}{9.632} & \multirow{3}{*}{0.01} \\
\hline & Within Groups & 514484.477 & 1859 & 276.753 & & \\
\hline & Total & 519815.785 & 1861 & & & \\
\hline \multirow{3}{*}{$\begin{array}{l}\text { Teaching of } \\
\text { Mathematics }\end{array}$} & Between Groups & 16412.243 & 2 & 8206.122 & \multirow{3}{*}{31.417} & \multirow{3}{*}{0.01} \\
\hline & Within Groups & 485576.677 & 1859 & 261.203 & & \\
\hline & Total & 501988.920 & 1861 & & & \\
\hline \multirow{3}{*}{$\begin{array}{l}\text { Teaching of } \\
\text { Science }\end{array}$} & Between Groups & 3184.775 & 2 & 1592.388 & \multirow{3}{*}{18.906} & \multirow{3}{*}{0.01} \\
\hline & Within Groups & 156576.275 & 1859 & 84.226 & & \\
\hline & Total & 159761.050 & 1861 & & & \\
\hline \multirow{3}{*}{$\begin{array}{c}\text { Teaching of } \\
\text { Social Science }\end{array}$} & Between Groups & 8556.663 & 2 & 4278.331 & \multirow{3}{*}{41.354} & \multirow{3}{*}{0.01} \\
\hline & Within Groups & 192325.903 & 1859 & 103.457 & & \\
\hline & Total & 200882.566 & 1861 & & & \\
\hline \multirow{3}{*}{$\begin{array}{c}\text { All Subjects / } \\
\text { Papers Total } \\
\text { mark }\end{array}$} & Between Groups & 342007.717 & 2 & 171003.859 & \multirow{3}{*}{46.614} & \multirow{3}{*}{0.01} \\
\hline & Within Groups & 6819720.515 & 1859 & 3668.489 & & \\
\hline & Total & 7161728.233 & 1861 & & & \\
\hline
\end{tabular}

The Table 11 shows that the calculated ' $F$ ' values $21.202,10.163,45.500,9.632,31.417,18.906$, 41.354 and 46.614 are greater than the table value 6.92 for $\mathrm{df}(2,1851)$ and hence the null hypothesis there exists no significant difference in mean achievement in the taught course among the teacher trainees of Pudukkottai District with respect to the variable - Type of Management of the Institute is rejected at 0.01 levels of significance.

8.1.1.1. Testing the significance of difference in mean achievement in the taught courses between the teacher trainees of Private (Majority) Management and Private (Minority) Management Institutes of Pudukkottai District 
The Dted. Curriculum / Syllabus of The State Tamilnadu In Inidia And Performance of Student

Table: 12 Mean, SD and ' $t$ ' value of Taught Courses between the teacher trainees of Private (Majority) and Private (Minority) Management Institutes of Pudukkottai District

\begin{tabular}{|c|c|c|c|c|c|c|c|}
\hline $\begin{array}{l}\text { Name of the } \\
\text { Subject / Paper }\end{array}$ & $\begin{array}{c}\text { Type of } \\
\text { Management of } \\
\text { the Institute }\end{array}$ & $\mathrm{N}$ & Mean & $\begin{array}{c}\text { Std. } \\
\text { Deviatio } \\
\text { n }\end{array}$ & $\mathrm{t}$ & df & $\begin{array}{l}\text { Sig. (2- } \\
\text { tailed) }\end{array}$ \\
\hline \multirow{2}{*}{ Learning Child } & Private (Majority) & 1542 & 73.8761 & $\begin{array}{r}13.8937 \\
1\end{array}$ & \multirow{2}{*}{3.258} & \multirow{2}{*}{1761} & \multirow{2}{*}{0.01} \\
\hline & Private (Minority) & 221 & 77.1267 & $\begin{array}{r}13.7296 \\
1 \\
\end{array}$ & & & \\
\hline \multirow{2}{*}{$\begin{array}{l}\text { Felicitating \& } \\
\text { Enhancing } \\
\text { Learning }\end{array}$} & Private (Majority) & 1542 & 84.9345 & $\begin{array}{r}10.7206 \\
4\end{array}$ & \multirow{2}{*}{3.377} & \multirow{2}{*}{1761} & \multirow{2}{*}{0.01} \\
\hline & Private (Minority) & 221 & 87.5385 & $\begin{array}{r}10.7231 \\
5\end{array}$ & & & \\
\hline \multirow{2}{*}{$\begin{array}{l}\text { Teaching of } \\
\text { Tamil }\end{array}$} & Private (Majority) & 1542 & 75.5519 & $\begin{array}{r}12.3221 \\
8\end{array}$ & \multirow{2}{*}{2.296} & \multirow{2}{*}{1761} & \multirow{2}{*}{0.05} \\
\hline & Private (Minority) & 221 & 77.5837 & $\begin{array}{r}12.1923 \\
4\end{array}$ & & & \\
\hline \multirow{2}{*}{$\begin{array}{l}\text { Teaching of } \\
\text { English }\end{array}$} & Private (Majority) & 1542 & 56.6602 & $\begin{array}{r}16.6455 \\
6 \\
\end{array}$ & \multirow{2}{*}{0.328} & \multirow{2}{*}{1761} & \multirow{2}{*}{ NS } \\
\hline & Private (Minority) & 221 & 56.2670 & $\begin{array}{r}16.6939 \\
4\end{array}$ & & & \\
\hline \multirow{2}{*}{$\begin{array}{l}\text { Teaching of } \\
\text { Mathematics }\end{array}$} & Private (Majority) & 1542 & 71.5785 & $\begin{array}{r}16.3305 \\
8\end{array}$ & \multirow{2}{*}{0.827} & \multirow{2}{*}{1761} & \multirow{2}{*}{ NS } \\
\hline & Private (Minority) & 221 & 72.5520 & $\begin{array}{r}16.5640 \\
2\end{array}$ & & & \\
\hline \multirow{2}{*}{$\begin{array}{l}\text { Teaching of } \\
\text { Science }\end{array}$} & Private (Majority) & 1542 & 81.2633 & 9.27855 & \multirow{2}{*}{1.429} & \multirow{2}{*}{1761} & \multirow{2}{*}{ NS } \\
\hline & Private (Minority) & 221 & 82.2081 & 8.57068 & & & \\
\hline \multirow{2}{*}{$\begin{array}{l}\text { Teaching of } \\
\text { Social Science }\end{array}$} & Private (Majority) & 1542 & 85.2808 & $\begin{array}{r}10.2248 \\
4 \\
\end{array}$ & \multirow{2}{*}{0.036} & \multirow{2}{*}{1761} & \multirow{2}{*}{ NS } \\
\hline & Private (Minority) & 221 & 85.3077 & $\begin{array}{r}10.7680 \\
2\end{array}$ & & & \\
\hline \multirow{2}{*}{$\begin{array}{l}\text { All Subjects / } \\
\text { Papers Total } \\
\text { mark }\end{array}$} & Private (Majority) & 1542 & 529.15 & 61.037 & \multirow[b]{2}{*}{2.150} & \multirow[b]{2}{*}{1761} & \multirow{2}{*}{0.05} \\
\hline & Private (Minority) & 221 & 538.58 & 60.962 & & & \\
\hline
\end{tabular}

The Table 12 clearly shows that ' $t$ ' values for the taught courses namely Learning Child and Felicitating $\&$ Enhancing Learning are greater than the table value for $\mathrm{df}=1761$ at 0.01 level of significance and also for the taught Teaching of Tamil and all the taught courses combined are greater than the table value for $\mathrm{df}=1761$ at 0.05 level of significance. It also shows that ' $t$ ' values for the taught courses Teaching of English, Teaching of Mathematics, Teaching of Science and Teaching of Social Science are less than the table value for $\mathrm{df}=1761$ at 0.05 level of significance. Hence the null hypothesis that there exists, no significant difference in mean achievement in the taught courses between the teacher trainees of Private (Majority) Management and Private (Minority) Management Institutes of Pudukkottai District is rejected for the taught courses Learning Child and Felicitating \& Enhancing Learning (0.01 level) and Teaching of Tamil and all the taught courses combined $(0.05)$ and accepted for the taught courses Teaching of English, Teaching of Mathematics, Teaching of Science and Teaching of Social Science (0.05).

8.1.1.2. Testing the significance of difference in mean achievement in the taught courses between the teacher trainees of Private (Majority) Management and Government Institutes of Pudukkottai District

Table 13 : Mean, SD and ' $t$ ' value of Taught Courses between the teacher trainees of Private (Majority) Management and Government Institutes of Pudukkottai District

\begin{tabular}{|c|c|r|r|r|r|r|c|}
\hline $\begin{array}{c}\text { Name of the } \\
\text { Subject / Paper }\end{array}$ & $\begin{array}{c}\text { Type of } \\
\text { Management of } \\
\text { the Institute }\end{array}$ & $\mathrm{N}$ & Mean & $\begin{array}{c}\text { Std. } \\
\text { Deviation }\end{array}$ & $\mathrm{t}$ & $\mathrm{df}$ & $\begin{array}{c}\text { Sig. } \\
(2- \\
\text { tailed) }\end{array}$ \\
\hline Learning Child & Private (Majority) & 1542 & 73.8761 & 13.89371 & 7.126 & $118^{*}$ & 0.01 \\
\cline { 2 - 9 } & Govt. & 99 & 82.2626 & 11.16809 & & \\
\hline Felicitating \& & Private (Majority) & 1542 & 84.9345 & 10.72064 & 3.252 & 1639 & 0.01 \\
\hline
\end{tabular}


The Dted. Curriculum / Syllabus of The State Tamilnadu In Inidia And Performance of Student

\begin{tabular}{|c|c|c|c|c|c|c|c|}
\hline $\begin{array}{l}\text { Enhancing } \\
\text { Learning }\end{array}$ & Govt. & 99 & 88.5253 & 9.48182 & & & \\
\hline \multirow{2}{*}{ Teaching of Tamil } & Private (Majority) & 1542 & 75.5519 & 12.32218 & 9.415 & 1639 & 0.01 \\
\hline & Govt. & 99 & 87.5253 & 11.33384 & & & \\
\hline \multirow{2}{*}{$\begin{array}{l}\text { Teaching of } \\
\text { English }\end{array}$} & Private (Majority) & 1542 & 56.6602 & 16.64556 & 4.334 & 1639 & 0.01 \\
\hline & Govt. & 99 & 64.1313 & 16.35115 & & & \\
\hline \multirow{2}{*}{$\begin{array}{l}\text { Teaching of } \\
\text { Mathematics }\end{array}$} & Private (Majority) & 1542 & 71.5785 & 16.33058 & 10.365 & $122^{*}$ & 0.01 \\
\hline & Govt. & 99 & 84.8586 & 12.05854 & & & \\
\hline \multirow{2}{*}{$\begin{array}{l}\text { Teaching of } \\
\text { Science }\end{array}$} & Private (Majority) & 1542 & 81.2633 & 9.27855 & 6.031 & 1639 & 0.01 \\
\hline & Govt. & 99 & 87.0505 & 8.89207 & & & \\
\hline \multirow{2}{*}{$\begin{array}{l}\text { Teaching of Social } \\
\text { Science }\end{array}$} & Private (Majority) & 1542 & 85.2808 & 10.22484 & 11.798 & 122 & 0.01 \\
\hline & Govt. & 99 & 94.8384 & 7.63278 & & & \\
\hline \multirow{2}{*}{$\begin{array}{c}\text { All Subjects / } \\
\text { Papers Total mark }\end{array}$} & Private (Majority) & 1542 & 529.15 & 61.037 & 11.087 & $116^{*}$ & 0.01 \\
\hline & Govt. & 99 & 589.19 & 51.623 & & & \\
\hline
\end{tabular}

- Equal variance not assumed

The Table 13 indicates that ' $t$ ' values for all the taught courses and combined are greater than the table value for $\mathrm{df}=(116,118,122,1639)$ at 0.01 level of significance Hence the null hypothesis there exists, no significant difference in mean achievement in the taught courses between the teacher trainees of Private (Majority) Management and Government Institutes of Pudukkottai District is rejected for all the taught courses and the combined.

8.1.1.3. Testing the significance of difference in mean achievement in the taught courses between the teacher trainees of Private (Minority) Management and Government Institutes of Pudukkottai District

Table 14 : Mean, SD and ' $t$ ' value of Taught Courses between the teacher trainees of Private (Minority) Management and Government Institutes of Pudukkottai District

\begin{tabular}{|c|c|c|c|c|c|c|c|}
\hline $\begin{array}{l}\text { Name of the } \\
\text { Subject / Paper }\end{array}$ & $\begin{array}{c}\text { Type of } \\
\text { Management of } \\
\text { the Institute }\end{array}$ & $\mathrm{N}$ & Mean & $\begin{array}{c}\text { Std. } \\
\text { Deviatio } \\
n\end{array}$ & $\mathrm{t}$ & $\mathrm{df}$ & $\begin{array}{l}\text { Sig. (2- } \\
\text { tailed) }\end{array}$ \\
\hline \multirow{2}{*}{ Learning Child } & Private (Minority) & 221 & 77.1267 & $\begin{array}{r}13.7296 \\
1\end{array}$ & \multirow{2}{*}{3.533} & \multirow{2}{*}{$229 *$} & \multirow{2}{*}{0.01} \\
\hline & Govt. & 99 & 82.2626 & $\begin{array}{r}11.1680 \\
9\end{array}$ & & & \\
\hline \multirow{2}{*}{$\begin{array}{l}\text { Felicitating \& } \\
\text { Enhancing } \\
\text { Learning }\end{array}$} & Private (Minority) & 221 & 87.5385 & $\begin{array}{r}10.7231 \\
5\end{array}$ & \multirow{2}{*}{0.788} & \multirow{2}{*}{318} & \multirow{2}{*}{ NS } \\
\hline & Govt. & 99 & 88.5253 & 9.48182 & & & \\
\hline \multirow{2}{*}{$\begin{array}{l}\text { Teaching of } \\
\text { Tamil }\end{array}$} & Private (Minority) & 221 & 77.5837 & $\begin{array}{r}12.1923 \\
4\end{array}$ & \multirow{2}{*}{6.888} & \multirow{2}{*}{318} & \multirow{2}{*}{0.01} \\
\hline & Govt. & 99 & 87.5253 & $\begin{array}{r}11.3338 \\
4\end{array}$ & & & \\
\hline \multirow{2}{*}{$\begin{array}{l}\text { Teaching of } \\
\text { English }\end{array}$} & Private (Minority) & 221 & 56.2670 & $\begin{array}{r}16.6939 \\
4\end{array}$ & \multirow{2}{*}{3.920} & \multirow{2}{*}{318} & \multirow{2}{*}{0.01} \\
\hline & Govt. & 99 & 64.1313 & $\begin{array}{r}16.3511 \\
5\end{array}$ & & & \\
\hline \multirow{2}{*}{$\begin{array}{l}\text { Teaching of } \\
\text { Mathematics }\end{array}$} & Private (Minority) & 221 & 72.5520 & $\begin{array}{r}16.5640 \\
2\end{array}$ & \multirow{2}{*}{7.475} & \multirow{2}{*}{$253^{*}$} & \multirow{2}{*}{0.01} \\
\hline & Govt. & 99 & 84.8586 & $\begin{array}{r}12.0585 \\
4\end{array}$ & & & \\
\hline \multirow{2}{*}{$\begin{array}{l}\text { Teaching of } \\
\text { Science }\end{array}$} & Private (Minority) & 221 & 82.2081 & 8.57068 & \multirow{2}{*}{4.618} & \multirow{2}{*}{318} & \multirow{2}{*}{0.01} \\
\hline & Govt. & 99 & 87.0505 & 8.89207 & & & \\
\hline \multirow{2}{*}{$\begin{array}{l}\text { Teaching of } \\
\text { Social Science }\end{array}$} & Private (Minority) & 221 & 85.3077 & $\begin{array}{r}10.7680 \\
2 \\
\end{array}$ & \multirow[t]{2}{*}{9.033} & \multirow[t]{2}{*}{$258 *$} & \multirow[t]{2}{*}{0.01} \\
\hline & Govt. & 99 & 94.8384 & 7.63278 & & & \\
\hline \multirow{2}{*}{$\begin{array}{c}\text { All Subjects / } \\
\text { Papers Total } \\
\text { mark }\end{array}$} & Private (Minority) & 221 & 538.58 & 60.962 & \multirow{2}{*}{7.185} & \multirow{2}{*}{318} & \multirow{2}{*}{0.01} \\
\hline & Govt. & 99 & 589.19 & 51.623 & & & \\
\hline
\end{tabular}

- Equal variance not assumed 
The Table 14 indicates that ' $t$ ' values for all the taught courses and combined except Felicitating \& Enhancing Learning are greater than the table value for $\mathrm{df}=(229,253,258,318)$ at 0.01 level of significance. Hence the null hypothesis there exists, no significant difference in mean achievement in the taught courses between the teacher trainees of Private (Minority) Management and Government Institutes of Pudukkottai District is rejected for all the taught courses and the combined except Felicitating \& Enhancing Learning.

8.1.1.4. Testing the significance of difference in mean achievement in the taught courses between the teacher trainees of Private Management and Government Institutes of Pudukkottai District

Table 15 : Mean, SD and ' $t$ ' value of Taught Courses between the teacher trainees of Private Management and Government Institutes of Pudukkottai District

\begin{tabular}{|c|c|c|c|c|c|c|c|}
\hline \multicolumn{8}{|c|}{ 然 } \\
\hline $\begin{array}{l}\text { Name of the } \\
\text { Subject / Paper }\end{array}$ & $\begin{array}{l}\text { Type of } \\
\text { Manage } \\
\text { ment of } \\
\text { the } \\
\text { Institute }\end{array}$ & $\mathrm{N}$ & Mean & $\begin{array}{c}\text { Std. } \\
\text { Deviatio } \\
n\end{array}$ & $\mathrm{t}$ & $\mathrm{df}$ & $\begin{array}{l}\text { Sig. (2- } \\
\text { tailed) }\end{array}$ \\
\hline \multirow{2}{*}{ Learning Child } & Private & 99 & 82.2626 & $\begin{array}{r}11.1680 \\
9\end{array}$ & \multirow{2}{*}{6.818} & \multirow{2}{*}{$116^{*}$} & \multirow{2}{*}{0.01} \\
\hline & Govt. & 1763 & 74.2836 & $\begin{array}{r}13.9111 \\
0\end{array}$ & & & \\
\hline \multirow{2}{*}{$\begin{array}{c}\text { Felicitating \& } \\
\text { Enhancing } \\
\text { Learning }\end{array}$} & Private & 99 & 88.5253 & 9.48182 & \multirow[b]{2}{*}{2.957} & \multirow[b]{2}{*}{1860} & \multirow[b]{2}{*}{0.01} \\
\hline & Govt. & 1763 & 85.2609 & $\begin{array}{r}10.7525 \\
6 \\
\end{array}$ & & & \\
\hline \multirow{2}{*}{$\begin{array}{l}\text { Teaching of } \\
\text { Tamil }\end{array}$} & Private & 99 & 87.5253 & $\begin{array}{r}11.3338 \\
4 \\
\end{array}$ & \multirow{2}{*}{9.246} & \multirow{2}{*}{1860} & \multirow{2}{*}{0.01} \\
\hline & Govt. & 1763 & 75.8066 & $\begin{array}{r}12.3209 \\
3 \\
\end{array}$ & & & \\
\hline \multirow{2}{*}{$\begin{array}{l}\text { Teaching of } \\
\text { English }\end{array}$} & Private & 99 & 64.1313 & $\begin{array}{r}16.3511 \\
5\end{array}$ & \multirow{2}{*}{4.378} & \multirow{2}{*}{1860} & \multirow{2}{*}{0.01} \\
\hline & Govt. & 1763 & 56.6109 & $\begin{array}{r}16.6473 \\
9 \\
\end{array}$ & & & \\
\hline \multirow{2}{*}{$\begin{array}{l}\text { Teaching of } \\
\text { Mathematics }\end{array}$} & Private & 99 & 84.8586 & $\begin{array}{r}12.0585 \\
4\end{array}$ & \multirow{2}{*}{10.336} & \multirow{2}{*}{$119 *$} & \multirow{2}{*}{0.01} \\
\hline & Govt. & 1763 & 71.7005 & $\begin{array}{r}16.3584 \\
6 \\
\end{array}$ & & & \\
\hline \multirow{2}{*}{$\begin{array}{l}\text { Teaching of } \\
\text { Science }\end{array}$} & Private & 99 & 87.0505 & 8.89207 & \multirow{2}{*}{5.979} & \multirow{2}{*}{1860} & \multirow{2}{*}{0.01} \\
\hline & Govt. & 1763 & 81.3817 & 9.19582 & & & \\
\hline \multirow{2}{*}{$\begin{array}{l}\text { Teaching of } \\
\text { Social Science }\end{array}$} & Private & 99 & 94.8384 & 7.63278 & \multirow[b]{2}{*}{11.864} & \multirow[b]{2}{*}{$119 *$} & \multirow[b]{2}{*}{0.01} \\
\hline & Govt. & 1763 & 85.2842 & $\begin{array}{r}10.2913 \\
5\end{array}$ & & & \\
\hline \multirow{2}{*}{$\begin{array}{l}\text { All Subjects / } \\
\text { Papers Total } \\
\text { mark }\end{array}$} & Private & 99 & 589.19 & 51.623 & \multirow{2}{*}{10.924} & \multirow{2}{*}{$114^{*}$} & \multirow{2}{*}{0.01} \\
\hline & Govt. & 1763 & 530.33 & 61.090 & & & \\
\hline
\end{tabular}

- $\quad$ Equal variance not assumed

The Table 15 indicates that ' $t$ ' values for all the taught courses and combined are greater than the table values (for $\mathrm{df}=114,116,119,1860$ ) at 0.01 level of significance. Hence the null hypothesis there exists, no significant difference in mean achievement in the taught courses between the teacher trainees of Private Management and Government Institutes of Pudukkottai District is rejected for all the taught courses and the combined.

8.1.2. Testing the significance of difference in mean achievement in the taught courses between the Male teacher trainees and Female teacher trainees of Pudukkottai District 
The Dted. Curriculum / Syllabus of The State Tamilnadu In Inidia And Performance of Student

Table 16: Mean, SD and ' $t$ ' value of Taught Courses between the Male teacher trainees and Female teacher trainees of Pudukkottai District

\begin{tabular}{|c|c|c|c|c|c|c|c|}
\hline $\begin{array}{l}\text { Name of the } \\
\text { Subject / Paper }\end{array}$ & Sex & $\mathrm{N}$ & Mean & $\begin{array}{c}\text { Std. } \\
\text { Deviatio } \\
\text { n }\end{array}$ & $\mathrm{t}$ & df & $\begin{array}{l}\text { Sig. (2- } \\
\text { tailed) }\end{array}$ \\
\hline \multirow{2}{*}{$\begin{array}{l}\text { Learning } \\
\text { Child }\end{array}$} & Male & 294 & 70.7653 & $\begin{array}{r}15.5459 \\
0\end{array}$ & \multirow{2}{*}{4.836} & \multirow{2}{*}{$379 *$} & \multirow{2}{*}{0.01} \\
\hline & Female & 1568 & 75.4471 & $\begin{array}{r}13.4371 \\
7\end{array}$ & & & \\
\hline \multirow{2}{*}{$\begin{array}{l}\text { Felicitating \& } \\
\text { Enhancing } \\
\text { Learning }\end{array}$} & Male & 294 & 82.5408 & $\begin{array}{r}11.4147 \\
7\end{array}$ & \multirow{2}{*}{4.796} & \multirow{2}{*}{$391 *$} & \multirow{2}{*}{0.01} \\
\hline & Female & 1568 & 85.9770 & $\begin{array}{r}10.4898 \\
3 \\
\end{array}$ & & & \\
\hline \multirow{2}{*}{$\begin{array}{l}\text { Teaching of } \\
\text { Tamil }\end{array}$} & Male & 294 & 71.9218 & $\begin{array}{r}12.3190 \\
2 \\
\end{array}$ & \multirow{2}{*}{6.794} & \multirow{2}{*}{1860} & \multirow{2}{*}{0.01} \\
\hline & Female & 1568 & 77.2749 & $\begin{array}{r}12.4113 \\
3\end{array}$ & & & \\
\hline \multirow{2}{*}{$\begin{array}{l}\text { Teaching of } \\
\text { English }\end{array}$} & Male & 294 & 51.2041 & $\begin{array}{r}15.8991 \\
9\end{array}$ & \multirow{2}{*}{6.565} & \multirow{2}{*}{1860} & \multirow{2}{*}{0.01} \\
\hline & Female & 1568 & 58.0995 & $\begin{array}{r}16.6417 \\
7\end{array}$ & & & \\
\hline \multirow{2}{*}{$\begin{array}{l}\text { Teaching of } \\
\text { Mathematics }\end{array}$} & Male & 294 & 67.1259 & $\begin{array}{r}16.8994 \\
6\end{array}$ & \multirow{2}{*}{5.872} & \multirow{2}{*}{$400^{*}$} & \multirow{2}{*}{0.01} \\
\hline & Female & 1568 & 73.3890 & $\begin{array}{r}16.1478 \\
2\end{array}$ & & & \\
\hline \multirow{2}{*}{$\begin{array}{l}\text { Teaching of } \\
\text { Science }\end{array}$} & Male & 294 & 79.4082 & 9.34420 & \multirow{2}{*}{4.613} & \multirow{2}{*}{1860} & \multirow{2}{*}{0.01} \\
\hline & Female & 1568 & 82.1097 & 9.19099 & & & \\
\hline \multirow{2}{*}{$\begin{array}{l}\text { Teaching of } \\
\text { Social Science }\end{array}$} & Male & 294 & 84.6020 & $\begin{array}{r}11.1698 \\
7 \\
\end{array}$ & \multirow{2}{*}{2.142} & \multirow{2}{*}{1860} & \multirow{2}{*}{0.05} \\
\hline & Female & 1568 & 86.0153 & $\begin{array}{r}10.2250 \\
3\end{array}$ & & & \\
\hline \multirow{2}{*}{$\begin{array}{l}\text { All Subjects / } \\
\text { Papers Total } \\
\text { mark }\end{array}$} & Male & 294 & 507.57 & 62.456 & \multirow{2}{*}{7.927} & \multirow{2}{*}{1860} & \multirow{2}{*}{0.01} \\
\hline & Female & 1568 & 538.31 & 60.759 & & & \\
\hline
\end{tabular}

- Equal variance not assumed

The Table 16 indicates that ' $t$ ' values for all the taught courses and combined are greater than the table values (for $\mathrm{df}=379,391,400,1860$ ) at 0.01 level of significance for all the taught courses except Teaching of Social Science which is greater than the table value at 0.05 level of significance. Hence the null hypothesis viz., there exists, no significant difference in mean achievement in the taught courses between the Male teacher trainees and Female teacher trainees of Pudukkottai District is rejected for all the taught courses and the combined.

8.1.3. Testing the significance of difference in mean achievement in the taught courses between the teacher trainees of Pudukkottai District with respect to their Age

Table 17: Mean, SD and ' $t$ ' value of Taught Courses between the teacher trainees of Pudukkottai District with respect to their Age

\begin{tabular}{|c|c|c|c|c|c|c|c|}
\hline $\begin{array}{c}\text { Name of the Subject } \\
\text { / Paper }\end{array}$ & Age & $\mathrm{N}$ & Mean & $\begin{array}{c}\text { Std. } \\
\text { Deviation }\end{array}$ & $\mathrm{t}$ & df & $\begin{array}{l}\text { Sig. (2- } \\
\text { tailed) }\end{array}$ \\
\hline \multirow[b]{2}{*}{ Learning Child } & $>=23.00$ & 542 & 74.1236 & 14.96532 & \multirow[b]{2}{*}{1.111} & \multirow{2}{*}{$917 *$} & \multirow{2}{*}{ NS } \\
\hline & $<23.00$ & 1320 & 74.9477 & 13.42566 & & & \\
\hline \multirow{2}{*}{$\begin{array}{c}\text { Felicitating \& } \\
\text { Enhancing Learning }\end{array}$} & $>=23.00$ & 542 & 84.4262 & 11.22601 & \multirow{2}{*}{2.607} & \multirow{2}{*}{1860} & \multirow{2}{*}{0.01} \\
\hline & $<23.00$ & 1320 & 85.8485 & 10.46934 & & & \\
\hline \multirow{2}{*}{ Teaching of Tamil } & $>=23.00$ & 542 & 75.1531 & 12.68649 & \multirow{2}{*}{2.818} & \multirow{2}{*}{1860} & \multirow{2}{*}{0.01} \\
\hline & $<23.00$ & 1320 & 76.9538 & 12.45535 & & & \\
\hline \multirow{2}{*}{ Teaching of English } & $>=23.00$ & 542 & 55.9502 & 16.78766 & \multirow{2}{*}{1.756} & \multirow{2}{*}{1860} & \multirow{2}{*}{ NS } \\
\hline & $<23.00$ & 1320 & 57.4462 & 16.66892 & & & \\
\hline Teaching of & $>=23.00$ & 542 & 70.8007 & 16.89866 & 2.697 & 1860 & 0.01 \\
\hline
\end{tabular}


The Dted. Curriculum / Syllabus of The State Tamilnadu In Inidia And Performance of Student

\begin{tabular}{|c|c|c|c|c|c|c|c|}
\hline Mathematics & $<23.00$ & 1320 & 73.0568 & 16.18559 & & & \\
\hline \multirow{2}{*}{ Teaching of Science } & $>=23.00$ & 542 & 80.1218 & 9.65428 & \multirow{2}{*}{4.686} & \multirow{2}{*}{1860} & \multirow{2}{*}{0.01} \\
\hline & $<23.00$ & 1320 & 82.3242 & 9.02667 & & & \\
\hline \multirow{2}{*}{$\begin{array}{l}\text { Teaching of Social } \\
\text { Science }\end{array}$} & $>=23.00$ & 542 & 85.0185 & 11.16767 & \multirow{2}{*}{2.061} & \multirow{2}{*}{1860} & \multirow{2}{*}{0.05} \\
\hline & $<23.00$ & 1320 & 86.1098 & 10.03984 & & & \\
\hline \multirow{2}{*}{$\begin{array}{c}\text { All Subjects / } \\
\text { Papers Total mark }\end{array}$} & $>=23.00$ & 542 & 525.59 & 66.041 & \multirow{2}{*}{3.379} & \multirow{2}{*}{$927 *$} & \multirow{2}{*}{0.01} \\
\hline & $<23.00$ & 1320 & 536.69 & 60.041 & & & \\
\hline
\end{tabular}

- $\quad$ Equal variance not assumed

The Table 17 indicates that ' $t$ ' values are greater than the table values (for $\mathrm{df}=917,927,1860$ ) at 0.01 level of significance for the taught courses Felicitating \& Enhancing Learning, Teaching of Tamil, Teaching of Mathematics, Teaching of Science and combined. The table also indicates that t' value is greater than the table value (for $\mathrm{df}=1860$ ) at 0.05 level of significance for the taught course Teaching of Social Science. Hence the null hypothesis viz., there exists, no significant difference in mean achievement in the taught courses between the teacher trainees of Pudukkottai District with respect to their Age is rejected for the taught courses Felicitating \& Enhancing Learning, Teaching of Tamil, Teaching of Mathematics, Teaching of Science, Teaching of Social Science and the combined. Teacher trainees with Age equal and less 23 years have achieved more in the taught courses Felicitating \& Enhancing Learning, Teaching of Tamil, and Teaching of Mathematics, Teaching of Science, Teaching of Social Science and the combined than the trainees with Age equal and less 23 years.

The Table 17 further shows that t' values are less than the table values (for $\mathrm{df}=917,1860$ ) at 0.05 level of significance for the taught courses Learning Child and Teaching of English. Hence the null hypothesis viz., there exists, no significant difference in mean achievement in the taught courses between the teacher trainees of Pudukkottai District with respect to their Age is accepted for the taught courses Learning Child and Teaching of English.

\subsection{Achievement of Teacher Trainees in the Practicum}

Table :18 Subject-wise Achievement of Teacher Trainees of Pudukkottai District in Practicum

\begin{tabular}{|c|c|c|c|}
\hline Subject & Grade & Frequency & Percent \\
\hline \multirow{3}{*}{ Observing Children and doing Case Study } & A & 845 & 45.4 \\
\hline & $\mathbf{B}$ & 796 & 42.7 \\
\hline & $\mathbf{C}$ & 221 & 11.9 \\
\hline \multirow{3}{*}{ School Visit } & $\mathbf{A}$ & 793 & 42.6 \\
\hline & $\mathbf{B}$ & 831 & 44.6 \\
\hline & $\mathbf{C}$ & 238 & 12.8 \\
\hline \multirow{3}{*}{ Story Telling } & $\mathbf{A}$ & 819 & 44.0 \\
\hline & $\mathbf{B}$ & 835 & 44.8 \\
\hline & $\mathbf{C}$ & 208 & 11.2 \\
\hline \multirow{3}{*}{$\begin{array}{c}\text { Physical Education, Health Education \& } \\
\text { Yoga }\end{array}$} & $\mathbf{A}$ & 901 & 48.4 \\
\hline & $\mathbf{B}$ & 761 & 40.9 \\
\hline & $\mathbf{C}$ & 200 & 10.7 \\
\hline \multirow{3}{*}{ Self- Development workshop } & $\mathbf{A}$ & 905 & 48.6 \\
\hline & $\mathbf{B}$ & 719 & 38.6 \\
\hline & $\mathbf{C}$ & 238 & 12.8 \\
\hline \multirow{3}{*}{ Teaching Learning Materials } & $\mathbf{A}$ & 968 & 52.0 \\
\hline & $\mathrm{B}$ & 698 & 37.5 \\
\hline & $\mathrm{C}$ & 196 & 10.5 \\
\hline
\end{tabular}

The Table 18 shows that in an average more than $46.8 \%$ of trainees have secured ' $A$ ' Grade, $41.5 \%$ of trainees have secured 'B' Grade and only $11.7 \%$ of trainees have secured ' $\mathrm{C}$ ' Grade. Teacher Trainees have secured a maximum percentage (52) of Grade ' $A$ ', in the subject Teaching Learning Materials and a minimum percentage (42.6) of Grade ' $A$ ', in the subject School Visit. Teacher Trainees have secured a maximum percentage (44.8) of Grade 'B', in the subject Story Telling and a minimum percentage (37.5) of Grade 'B', in the subject Teaching Learning Materials. Teacher Trainees have secured a negligible percentage (12.8) of Grade ' $\mathrm{C}$ ', in the practicum subject 'School Visit'. In an average, the trainees have secured around $88.3 \%$ of 'A' and ' $B$ ' Grades in the practicum. This shows clearly that the 'practicum' introduced in the new syllabus has improved the overall performance of trainees with reference to 'Teaching Learning Materials, 'Story Telling' etc. 
The Dted. Curriculum / Syllabus of The State Tamilnadu In Inidia And Performance of Student

8.3. Achievement of Teacher Trainees in the Internship
Table :19 Subject-wise Achievement of Teacher Trainees of Pudukkottai District in Inte
\begin{tabular}{|c|c|c|c|}
\hline Subject & Grade & Frequency & Percent \\
\hline \multirow{3}{*}{ Teaching of Tamil } & A & 947 & 50.9 \\
\cline { 2 - 4 } & B & 731 & 39.3 \\
\cline { 2 - 4 } & C & 184 & 9.9 \\
\hline \multirow{3}{*}{ Teaching of English } & A & 639 & 34.3 \\
\cline { 2 - 4 } & B & 967 & 51.9 \\
\cline { 2 - 4 } & C & 256 & 13.7 \\
\hline \multirow{3}{*}{ Teaching of Mathematics } & A & 867 & 46.6 \\
\cline { 2 - 4 } & B & 784 & 42.1 \\
\cline { 2 - 4 } & C & 211 & 11.3 \\
\hline \multirow{3}{*}{ Teaching of Science } & A & 871 & 46.8 \\
\cline { 2 - 4 } & B & 806 & 43.3 \\
\cline { 2 - 4 } & C & 185 & 9.9 \\
\hline \multirow{2}{*}{ Teaching of Social Science } & A & 796 & 42.7 \\
\cline { 2 - 4 } & B & 866 & 46.5 \\
\cline { 2 - 4 } & C & 200 & 10.7 \\
\hline
\end{tabular}

The Table 19 shows that in an average more than $44.3 \%$ of trainees have secured ' $A$ ' Grade, $44.6 \%$ of trainees have secured 'B' Grade and only $11.1 \%$ of trainees have secured ' $\mathrm{C}$ ' Grade. Teacher Trainees have secured a maximum percentage (50.9) of Grade ' $A$ ', in the subject Teaching of Tamil and a minimum percentage (34.3) of Grade ' $A$ ', in the subject Teaching of English. Teacher Trainees have secured a maximum percentage (51.9) of Grade 'B', in the subject Teaching of English and a minimum percentage (39.3) of Grade ' $\mathrm{B}$ ', in the subject Teaching of Tamil. Teacher Trainees have secured a maximum percentage (13.7) of Grade ' $\mathrm{C}$ ', in the subject Teaching of English and a minimum percentage (9.9) of Grade ' $C$ ', in the subject Teaching of Tamil. In an average, the trainees have secured around $88.9 \%$ of ' $A$ ' and ' $B$ ' Grades in the Internship. This reveals that performance of trainees in mother tongue is remarkably high and the performance of teaching of English to be strengthened.

\section{Results and Discussion}

The present study reveals that there exists significant difference in mean achievement in the taught course among the teacher trainees of Pudukkottai District with respect to the variables Type of Management of the Institute. The teacher trainees of Government Institute have recorded higher achievement in all the taught courses and the Combined than the teacher trainees of Private Management. The teacher trainees of Government Institute exhibit higher performance in all the taught courses and the Combined than the teacher trainees of Private (Majority) Management. The teacher trainees of Government Institute have put in relatively better performance in all the taught courses except Felicitating \& Enhancing Learning than the teacher trainees of Private (Minority) Management. The teacher trainees of Private (Minority) Management have achieved more in the taught courses Learning Child and Felicitating \& Enhancing Learning, Teaching of Tamil and all the taught courses combined than the teacher trainees of Private (Majority) Management. The order of achievement is Government, private (minority management) and Private (majority management) institution. Since most of the training institutes are privately managed the poor attainment is a serious concern for the teacher education programe. This evinces a special care is to be taken to study the problems of Private teacher training institutes.

The Female teacher trainees have scored significantly in all the taught courses and the Combined higher than the Male teacher trainees of Pudukkottai District. This shows that female trainees have higher propensity towards elementary teacher education than those of male.. Similar results were reported by Erten (2009), Isiksal (2005), Balasubramaniyan et al., (2001) and Behera et al., (2004). But the findings of the study by Arigbabu et al. (2004), and Moses et al. (2008), reveal that the gender gap in mathematics achievement among the sample data could be disappearing among the Nigerian Preservice Teachers. Studies conducted in India by Patil (1984), Gopal (1984) and Fairman et al., (1996) reported no significant difference in academic performance of teacher trainees.

The present study reveals that Age plays a role in the achievement of trainees with respect to all the taught courses except the taught courses Learning Child and Teaching of English. The trainees who are equal and less than 23 years old have recorded higher achievement than the trainees who are more than 23 years old. Thus it is essential to have a bridge course for those who entered the training programme after 3 years of higher secondary course. Perry et al. (2005) reported that no statistically significant differences were found between three age groups: 20 years or less; 21 to 30 years; over 30 years in academic achievement among teacher trainees. 


\section{The Dted. Curriculum / Syllabus of The State Tamilnadu In Inidia And Performance of Student}

In the practicum Teacher Trainees have secured a maximum percentage (52) of Grade 'A', in the subject Teaching Learning Materials and a minimum percentage (42.6) of Grade 'A', in the subject School Visit. In an average, the trainees have secured $88.3 \%$ of ' $A$ ' and 'B' Grades in the practicum. However, Teacher Trainees have secured only a negligible percentage (12.8) of Grade ' $\mathrm{C}$ ', in the subject School Visit. This shows clearly that the 'practicum' introduced in the new syllabus has improved the overall performance of trainees with reference to 'Teaching Learning Materials, 'Story Telling' etc.

In the internship Teacher Trainees have secured a maximum percentage (50.9) of Grade ' $A$ ', in the subject Teaching of Tamil (Mother tongue) and a minimum percentage (34.3) of Grade 'A', in the subject Teaching of English. Teacher Trainees have secured a maximum percentage (13.7) of Grade ' $\mathrm{C}$ ', in the subject Teaching of English and a minimum percentage (9.9) of Grade ' $\mathrm{C}$ ', in the subject Teaching of Tamil. This shows more attention should be given to the trainees in order to teach English with confidence. Similar subject-wise difference was reported by Balasubramniyan et al., (2004). The overall picture shows that there is clearly some association between theory and internship components. In fact it is more revealing that in both theory and internship, trainees performance in English is rather low.

\section{Conclusion}

The present study was conducted to study the achievement of DTEd., trainees of Pudukkottai District with respect to the variables type of management of the institute, sex and Age of the trainees. The results of the present study shows that the teacher trainees of Government institute have scored better than the trainees of Private Management. From these findings there is a wake-up call for the policy makers to improve the quality of elementary teacher education in the private sector which has a lion's share of candidates on their roles. The achievement of female is more than that of male. This finding justifies the importance of appointing more female teachers in the elementary schools. The trainees having age equal and less than 23 years have obtained more achievement than the having age greater than 23 years except the taught courses Learning Child and Teaching of English. This shows that a well designed bridge courses is needed for the trainees who are entering the course after 3 years of completing higher secondary course.

\section{References}

[1] Abayomi A. Arigbabu., \& A. Mji., (2004) Is Gender a Factor in Mathematics Performance Among Nigerian Preservice Teachers? Sex Roles 51 11-12

[2] Afuwape Moses O., \& Oludipe Daniel I (2008) Gender difference in integrated science achievement among pre service teachers in Nigeria Educational Research and Review 3 (7), pp. 242-245

[3] Atan Long. (1984). Teacher's role and task in development country//Teacher and education. Selangor: Fajar Bakti Sdn.

[4] Balasubra,aniayn.P., \& Sivakumar.R A (2001) Comparative Study of Academic Achievement of Primary teachers Training Students, The Educational Review 44 (12) pp 226-228

[5] Ball, D. L., Hill, H. C. \& Bass, H.: 2005, Knowing mathematics for teaching: who knows mathematics well enough to teach third grade, and how can we decide? American Educator, 14-22 \& 43-46

[6] Fairman., Richard (1996) Assessing Teacher Concern at Three levels of Experience in a Pre-service Teacher Education Programme. 9639419 Dissertation Abstract International 57. pp 2972

[7] Gopal Charyulu, R.V. (1984) A study of Relationship between certain psychological factors and achievement of student teachers in Teacher Training of Institutions. Andhra Pradesh. M.B. Buch, Fourth Survey of Research in Education (1983-85) pp940. NCERT, New Delhi.

[8] Ismail Hakk1 Erten (2009) Gender differences in academic achievement among Turkish prospective teachers of English as a foreign language European Journal of Teacher Education, 32 (1) pp 75 - 91

[9] Kok-Aun Toh, Boon-Tiong Ho, Joseph P. Riley \& Yin-Kiong Hoh (2006) Meeting the highly qualified teachers challenge Educational Research for Policy and Practice 5 ( 3 )

[10] Laxmidhar Behera., \& Sushant Kumar Roul (2004) Performance of BE.d Trainees in relation of their Gender, Academic Background and Type of Institution. Educational Review 47 (1) pp 226-228

[11] Ministry of Education, Government of India National Education Policy 1986 \& POA (1992)

[12] Ministry of Education, Government of India, Report of the Education Commission 1964-66, New Delhi

[13] Ministry of Education, Government of India, Learning Without Burden - Report of the National Advisory Committee Author: Government of India (Yaspal Committee Report-1993)

[14] Mohd Sahandri Gani B. Hamzah, Hapidah Bt. Mohamed, Saifuddin Kumar B. Abdullah, \& Roselan B. Baki (2008) Working commitment among trainee teachers: A meta evaluation approach 5, (10) (Serial No.47) US-China Education Review,, USA

[15] National Curriculum Framework for Teacher Education Draft (2006) NCTE, \& NCERT New Delhi

[16] Patil, G.G. (1984) A differential study of Intelligence, Interest and Attitude of B.Ed College Students as contributory factor towards their achievement in compulsory subjects M.B. Buch, Fourth Survey of Research in Education (1983-85) pp940. NCERT, New Delhi

[17] Perry, B., Way, J., Southwell, B., White, A., \& Pattison, J. (2005). Mathematical beliefs and achievement of pre-service primary teachers. In P. Clarkson, A. Downton, D. Gronn, M. Horne, A. McDonough, R. Pierce, and A. Roche (Eds.), Building connections: Research, theory and practice (Proceedings of the 28th annual conference of the Mathematics Education Research Group of Australasia, Vol. 2, pp. 625-632). Sydney: MERGA.

[18] Rivkin, Steven G., Eric A. Hanushek, \& John F. Kain. (2001). "Teachers, schools, and academic achievement." Working Paper No. 6691, National Bureau of Economic Research (revised)

[19] Sanders, William L., \& Sandra P. Horn. (1994). "The Tennessee value-added assessment system (TVAAS): Mixed-model methodology in educational assessment." Journal of Personnel Evaluation in Education 8, pp 299-311.

[20] Taro Fujita., \& Keith Jones (2006) Primary Trainee Teachers' Knowledge of Parallelograms In Hewitt, D. (2006) Proceedings of the British Society for Research into Learning Mathematics 26(2)

[21] Wilson, S., Floden, R., \& Ferrini-Mundy, J. (2001). Teacher preparation research: Current knowledge, gaps, and recommendations. Washington, DC: Center for the Study of Teaching and Policy. 